\title{
Pengaruh Motivasi Belajar Terhadap Prestasi Belajar Siswa Kelas X Mia Di SMA Negeri 2 Namlea
}

\author{
Sitti Hajiyanti Makatita ${ }^{1 *}$, Azwan $^{1}$ \\ ${ }^{1}$ Universitas Iqra Buru / Fakultas Keguruan dan Ilmu Pendidkan \\ *E-mail: sitti.hajiyanti@gmail.com
}

\begin{abstract}
Abstrak: Dalam membantu anak meningkatkan prestasi belajar, pendidik terutama guru harus menciptakan iklim yang merangsang pemikiran dan ketrampilan kreatif anak di sekolah. faktor-faktor yang mempengaruhi proses belajar adalah faktor yang berasal dari siswa atau disebut dengan faktor internal, dan faktor yang berasal dari luar dalam diri siswa yang disebut faktor eksternal. Penelitian ini bertujuan untuk mengetahui pengaruh motivasi belajar terhadap prestasi belajar siswa pada mata pelajaran biologi di kelas $\mathrm{X}$ MIA SMA Negeri 2 Buru Kecamatan Namlea Kabupaten Buru. Sampel berjumlah 40 Orang. Rancangan penelitian ini adalah dengan menggunakan pendekatan kuantitatif, dengan tipe penelitian ex-post-facto. Pengambilan data variabel bebas diambil dengan menggunakan angket dengan skala likert, sedangkan data variabel terikat dikumpulkan dari data dokumen sekolah. Data tersebut kemudian akan diuji prasyarat selanjutnya dianalisis dengan menggunakan analisis regresi sederhana melalui program statistik SPSS 23.0. Hasil Penelitian menunjukan bahwa motivasi belajar berpengaruh atau mempunyai hubungan dengan prestasi belajar biologi siswa dan kontribusi motivasi belajar terhadap prestasi belajar sebesar $56,1 \%$
\end{abstract}

\section{Kata Kunci: Motivasi, Prestasi Belajar}

Abstract: In helping children improve their learning achievement, educators, especially teachers, must create a climate that stimulates children's creative thinking and skills at school. The factors that influence the learning process are factors that come from students or are called internal factors, and factors that come from outside within students are called external factors. This study aims to determine the effect of learning motivation on student achievement in biology subjects in class X MIA SMA Negeri 2 Buru, Namlea District, Buru Regency. The sample is 40 people. The design of this research is to use a quantitative approach, with the type of ex-post-facto research. Independent variable data collection was taken using a questionnaire with a Likert scale, while the dependent variable data was collected from school document data. The data will then be tested for prerequisites and then analyzed using simple regression analysis through the statistical program SPSS 23.0. The results showed that learning motivation had an effect on or had 
a relationship with students' biology learning achievement and the contribution of learning motivation to learning achievement was $56.1 \%$.

\section{Keywords: Motivation; Learning Achievement.}

Pendidikan bertujuan untuk mengembangkan potensi peserta didik agar menjadi manusia yang beriman dan bertakwa kepada Tuhan Yang Maha Esa, berakhlak mulia, sehat, berilmu, kreatif, mandiri dan menjadi warga negara yang demokratis serta bertanggung jawab. Pendidikan merupakan sarana dala menyediakan lingkungan yang memungkinkan anak didik untuk mengembangkan bakat dan kemampuannya secara optimal, sehingga dapat mewujudkan dirinya dan berfungsi sepenuhnya sesuai dengan kebutuhan pribadinya dan kebutuhan masyarakat. Dalam mebantu anak meningkatkan prestasi belajar pendidik terutama guruharus menciptakan iklim yang merangsangpemikiran dan ketrampilan kreatif anak di sekolah. Selain itu motivasi belajar sangat berperan dalam menentukan prestasi belajar siswa, motivasi belajar merupakan pendorong seorang peserta didik dalam melakukan aktivitas belajar. Dengan prestasi belajar yang baik berarti di dalam diri siswa ada keinginan untuk memperbaiki kegagalan yang lalu dengan usaha yang baru. Motivasi belajar inilah yang menumbuhkan rasa ingin menjadi lebih dari pada teman-temannya. Kekuatan mental itu berupa keinginan, perhatian, kemauan, atau citacita. Kekuatan mental tersebut dapat tergolong rendah atau tinggi. Anak yang termotivasi tentu akan belajar dengan rajin tanpa paksaan sedangkan anak yang kurang termotivasi tentu akan kurang serius dalam belajar baik di rumah atau di sekolah. Sehingga Siswa yang bermotivasi tinggi dalam belajar memungkinkan akan memperoleh hasil belajar yang tinggi pula, artinya semakin tinggi motivasinya, semakin intensitas usaha untuk meningkatkan keberhasilan dalam belajar sehingga mencapai keberhasilan yang cukup memuaskan sebagaimana yang diharapkan.

SMA Negri 2 merupakan salah satu Sekolah Menengah Atas (SMA) yang terdapat di kota Namlea kabupaten Buru. Sekolah tersebut termasuk sekolah dengan peminat yang cukup banyak dan dibilang sangat unggulan dari beberapa sekolah yang terdapat di kota namlea karna prestasi yang diraih selalu baik. Berdasarkan data hasil ujian akhir semester (UAS) pada Tahun Ajaran 2018/2019 (semester genap), rata-rata nilai biologi siswa kelas $X$ MIA berada di atas nilai kriteria ketuntasan minimal $(\geq 70)$ yang dikeluarkan sekolah. Hal tersebut bisa disebabkan karna banyak faktor yang mempengaruhi keadaan tersebut. Slameto (2015), menyatakan bahwa faktor-faktor yang mempengaruhi proses belajar adalah faktor yang berasal dari siswa atau disebut dengan faktor internal, dan faktor yang berasal dari luar dalam diri siswa yang disebut faktor eksternal. Faktor internal meliputi faktor psikologis (kondisi psikologis umum dan kondisi panca indera) dan faktor psikomotor (kecerdasan, minat, bakat, motivasi, kreatifitas dan kemampuan kognitif). Sedangkan faktor eksternal meliputi faktor lingkungan (lingkungan alami dan lingkungan 
sosial) dan faktor instrumental (program kurikulum, guru atau tenaga pengajar, dan fasilitas sekolah).

Penelitian ini bertujuan untuk mengetahui pengaruh motivasi belajar teerhadap prestasi belajar siswa kelas X MIA SMA Negeri 2 Buru Kecamatan Namlea Kabupaten Buru. Sampel berjumlah 40 Orang. Rancangan penelitian ini adalah dengan menggunakan pendekatan kuantitatif, dengan tipe penelitian ex-post-facto. Pengambilan data variabel bebas diambil dengan menggunakan angket dengan skala likert, sedangkan data variabel terikat dikumpulkan dari data dokumen sekolah. Data tersebut kemudian akan diuji prasyarat selanjutnya dianalisis dengan menggunakan analisis regresi melalui program statistik SPSS 23.0

\section{METODE PENELITIAN}

Penelitian yang akan dilaksanakan ini termasuk penelitian kuantitatif yaitu pendekatan yang akan menuntut menggunakan angka, mulai dari pengupulan data, penafsiran terhadap data tersebut, serta penampilan dari hasilnya. Jenis penelitian ini merupakan penelitian ex-post-facto. Penelitian ex post facto adalah pengamatan dilakukan setelah kejadian lewat. Penelitian ini dilakukan di SMA Negeri 2 Buru Kecamatan Namlea Kabupaten Buru pada bulan Juni - September 2020.

Populasi Penelitian dan Sampel

Populasi dalam penelitian ini adalah siswa kelas X Jurusan MIA SMA Negeri 2 Buru. Sampel yang digunakan dalam penelitian ini adalah siswa Kelas X MIA yang berjumlah 40 orang. Terdapat dua variabel penelitian yaitu: Variabel bebas/ independent variabel (X), yaitu: Motivasi Belajar dan Variabel terikat/ dependent variabel (Y), yaitu: Prestasi Belajar Siswa

Instrumen yang digunakan yakni angket/kuesioner dan nilai raport. Angket digunakan untuk memperoleh data mengenai motivasi belajar siswa. Kuesioner merupakan teknik pengumpulan data yang dilakukan dengan cara memberi seperangkat pertanyaan atau pernyataan tertulis kepada responden untuk dijawabnya (Sugiyono, 2012: 199). Kuesioner merupakan teknik pengumpulan data yang efisien bila peneliti tahu dengan pasti variabel yang akan diukur dan tahu apa yang bisa diharapkan dari responden. Peneliti memilih menggunakan kuesioner karena teknik pengumpulan data lebih efisien, praktis, dan sangat memungkinkan jika digunakan untuk responden yang cukup besar. Dalam pengumpulan informasi tentang motivasi belajar siswa, peneliti menggunakan kuesioner dengan bentuk kuesioner tertutup.'

Skala pengukuran yang digunakan dalam penelitian menggunakan kuesioner ini adalah model skala Likert. Skala Likert digunkana untuk mengukur sikap dalam suatu penelitian. Dengan penggunaan skala pengukuran, maka nilai variabel yang diukur dengan instrumen dapat dinyatakan dalam bentuk angka, sehingga akan lebih akurat, efisien, dan komunikatif. Menurut Sukardi (2011: 146), skala Likert telah banyak 
digunakan oleh para peneliti guna mengukur persepsi atau sikap seseorang. Skala Likert digunakan untuk mengukur sikap, pendapat, dan persepsi seseorang atau sekelompok orang tentang fenomena sosial. Dengan skala Likert, maka variabel yang akan diukur dijabarkan menjadi indikator variabel. Kemudian indikator tersebut dijadikan sebagai titik tolak untuk menyusun item-item instrumen yang dapat berupa pernyataan atau pertanyaan (Sugiyono, 2010: 134-135).

Jawaban dari setiap item instrumen yang menggunakan skala Likert mempunyai gradasi dari sangat positif sampai sangat negatif. Untuk menskor skala kategori Likert, jawaban diberi bobot atau disamakan dengan nilai kuantitatif 4, 3, 2, 1, untuk pilihan pernyataan positif, dan kebalikannya untuk pilihan pernyataan negatif. Sedangkan nilai raport digunakan untuk melihat prestasi belajar pada mata pelajaran biologi siswa kelas X Jurusan MIA SMA Negeri 2 Buru Kecamatan Namlea Kabupaten Buru

Teknik Pengumpulan Data: Angket, yang sudah buat disebarkan pada siswa, Angket yang telah diisi kemudian dikumpulkan dan diperiksa kelengkapannya, serta memeriksa kebenaran pengisiannya, Semua angket yang telah terkumpul kemudian diberikan nilai sesuai dengan sistem penilaian yang telah ditetapkan, Selanjutnya di analisis untuk mendapatkan presentasinya, Data yang telah diperoleh kemudian peneliti tetapkan sebagai data motivasi belajar siswa, dan Mengambil data yang sudah tersedia dalam Nilai Raport yaitu nilai hasil belajar siswa pada mata pelajaran Biologi yang merupakan hasil penilaian dari guru mata pelajaran.

Analisis data pada penelitian ini digunakan analisis data statistik melalui program SPSS 23.0. Data penelitian yang diperoleh dianalisis dengan statistik deskriptif dan statistik inferensial. Statistik deskriptif akan menggambarkan data yang telah terkumpul sebagaimana adanya dengan menampilkan data meliputi distribusi freku-ensi, total skor, harga skor rata-rata, simpang-an baku, modus, median, skor maksimum, skor minimum yang disertai dengan diagram batang. Kemudian data tersebut akan dides-kripsikan dalam sebuah kriteria penilaian. Statistik inferensial akan dianalisis terhadap tiap variable independen dan variable dependen dengan menggunakan analisis regresi sederhana. Sebelumnya dilakukan uji persyaratan analisis antara lain uji normalitas dan uji linieritas.

\section{HASIL DAN PEMBAHASAN}

Hasil uji normalitas data menggunakan One-Sample Kolmogrof Smirnov, Ditampilkan pada Tabel 1. 
Tabel 1. Uji Normalitas Data

\begin{tabular}{llr}
\hline & & Unstandardized Residual \\
\hline $\mathrm{N}$ & & 40 \\
Normal Parameters & Mean &, 0000000 \\
& Std. Deviation & 1,57214459 \\
Most Extreme Differences & Absolute &, 156 \\
& Positive &, 156 \\
& Negative &,- 112 \\
Test Statistic & &, 156 \\
Asymp. Sig. (2-tailed) & & $0,206^{\mathrm{c}}$ \\
\hline
\end{tabular}

Berdasarkan data pada tabel 1, menunjukan data berdistribusi normal dimana nilai sig lebih besar dari $\alpha(0,206>0,05)$. Sehingga Data Residual bisa dianalisis lanjut menggunakan regresi sederhana. Kontribusi motivasi belajar terhadap hasil belajar ditampilkan pada Tabel 2.

Tabel 2. Kontribusi Motivasi Belajar terhadap Prestasi Belajar

\begin{tabular}{|l|r|r|r|r|}
\hline \multirow{2}{*}{ Model } & R & R Square & $\begin{array}{c}\text { Adjusted R } \\
\text { Square }\end{array}$ & $\begin{array}{c}\text { Std. Error of the } \\
\text { Estimate }\end{array}$ \\
\hline 1 &, $749^{a}$ &, 561 &, 549 & 1,593 \\
\hline
\end{tabular}

Berdasarkan Tabel 2. Menunjukan bahwa motivasi belajar memiliki kekuatan hubungan yang sedang dengan hasil belajar biologi siswa, hal ini ditunjukan dengan nilai $\mathrm{R}$ sebesar 0,749. Sementara itu nilai R Square sebesar 0, 749 yang berarti motivasi belajar meiliki kontribusi atau pengaruh sebesar 56,1 \% terhadap hasil belajar biologi siswa, sedangkan 43,9\% lainnya dipengaruhi oleh faktor lain diluar motivasi belajar.

Analisis regresi sederhana menggunakan ANOVA dengan ketentuan jika nilai signifikansi lebih kecil dari $\alpha=0,05$. Hasil uji ANOVA ditampilkan pada Tabel 3 .

Tabel 3. Hasil uji ANOVA motivasi belajar dengan hasil belajar

\begin{tabular}{|c|c|c|c|c|c|}
\hline Model & $\begin{array}{l}\text { Sum of } \\
\text { Squares }\end{array}$ & df & $\begin{array}{l}\text { Mean } \\
\text { Square }\end{array}$ & $\mathrm{F}$ & Sig. \\
\hline \multirow[t]{3}{*}{1} & 123,106 & 1 & 123,106 & 48,530 &, $000^{\mathrm{b}}$ \\
\hline & 96,394 & 38 & 2,537 & & \\
\hline & 219,500 & 39 & & & \\
\hline
\end{tabular}

Berdasarkan data pada Tabel 3 menunjukan bahwa nilai sig adalah 0,000 yang menandakan bahwa model regresi dapat memprediksi hasil belajar siswa. Langkah selanjutnya adalah uji koofisien regresi yang ditampilkan pada tabel 4.

Tabel 4. Hasil Uji Koofisien Regresi

\begin{tabular}{|c|c|c|c|c|c|c|}
\hline \multirow{2}{*}{\multicolumn{2}{|c|}{ Model }} & \multicolumn{2}{|c|}{ Unstandardized Coefficients } & \multirow{2}{*}{$\begin{array}{c}\begin{array}{c}\text { Standardized } \\
\text { Coefficients }\end{array} \\
\text { Beta }\end{array}$} & \multirow[b]{2}{*}{$\mathrm{t}$} & \multirow[b]{2}{*}{ Sig. } \\
\hline & & B & Std. Error & & & \\
\hline \multirow[t]{2}{*}{1} & (Constant) & 46,080 & 5,270 & & 8,744 & , 000 \\
\hline & Motivasi Belajar & ,349 &, 050 & ,749 & 6,966 &, 000 \\
\hline
\end{tabular}

BIOLOGI SEL (VOL 10 NO 1 EDISI JAN-JUN 2021 ISSN 2252-858X/E-ISSN 2541-1225)PAGE 38 
Berdasarkan data pada Tabel 4 menunjukan bahwa nilai sig 0,000 lebih kecil dari a 0,05 yang menandakan koefisien regresi adalah signifikan. Persamaan regresinya adalah $\mathrm{Y}=46,080+0,349 \mathrm{X}$. Model Regresi menunjukan bahwa setiap kenaikan satu unit motivasi belajar maka akan meningkat pula hasil belajar siswa pada ujian semester sebesar 0,349 unit pada konstanta 46,080. Artinya semakin baik motivasi belajar siswa maka hasil belajarnya juga akan semakin tinggi, sebaliknya semakin rendah motivasi belajar siswa maka hasil belajarnya juga menurun.

Motivasi memiliki pengaruh terhadap prestasi belajar. Prestasi belajar siswa akan baik jika tertanam motivasi yang kuat dalam diri mereka. Hasil penelitian ini sejalan dengan penelitian Inayah dkk (2013) menyimpulkan bahwa terdapat hubungan positif antara motivasi dan prestasibelajar pada mata pelajaran ekonomi. Motivasi belajar siswa tidaklah sama, ada siswa yang mememiliki motivasi yang tinggi dan ada mahasiswa yang memiliki motivasi yang rendah. Hal ini ditunjukan dengan skor angket motivasi yang berbeda dimana skor minimum 94 dan skor maksimum 119. Menurut Daskalovska et.al (2012) menyatakan bahwa semua pembelajar didalam kelas tidak memiliki level dan jenis motivasi yang sama.

Motivasi merupakan dorongan dari dalam diri dan dari luar diri seorang siswa yang membuat siswa terdorong untuk melakukan sesuatu dalam mencapai tujuan yang ingin dicapai. Tujuan siswa dalam belajar adalah meperoleh hasil belajar yang baik. Menurut Hamdu dan Agustina (2011) peningkatan hasil belajar siswa dipengaruhi oleh beberapa faktor, salah satunya adalah motivasi untuk belajar.Pada penelitian ini motivasi memiliki kontribusi atau pengaruh terhadap prestasi belajar dari hasil penelitian menunjukan bahwa motivasi belajar mempunyai kontribusi sebesar 56,1 \%. Hasil penelitian ini sejalan dengan penelitian yang telah dilakukan oleh Firmansyah (2011), Lee (2010) dan Insar dkk (2017) yang menyimpulkan bahwa Motivasi memiliki pengaruh atau kontribusi terhadap hasil belajar atau prestasi belajar siswa.

\section{KESIMPULAN}

Kesimpulan dalam penelitian ini adalah terdapat hubungan motivasi belajar dengan prestasi belajar biologi siswa kelas X MIA SMA Negri 2 Namlea kabupaten Buru. Motivasi memiliki kontribusi atau pengaruh terhadap prestasi belajar. Semakin tinggi Motivasi belajar maka prestasi belajar akan semakin baik.

\section{DAFTAR PUSTAKA}

Daskalovska, N, Gudeva, L. K, \& Ivanovska, B (2012). Leaner Motivation and Interest Procedia- Sosial and Behavional Science,46, 1187-1191

Firmansyah, H. (2011). Hubungan Motivasi Berprestasi Siswa Dengan Hasil Belajar Pendidikan Jasmani. Jurnal PendidikanJasmani Indonesia, 6(1)30-33 
Hamdu G., \& Agustina, L. (2011). Pengaruh Motivasi Belajar Siswa Terhadap Prestasi Belajar IPA Di Sekolah Dasar (Studi Kasus terhadap Siswa Kelas IV SDN Tarumanagara Kecamatan Tawang Kota Tasikmalaya). Jurnal Penelitian Pendidikan, 12(1), 81-86.

Inayah, R. (2013). Pengaruh Kompetensi Guru, Motivasi Belajar Siswa dan Fasilitas Belajar Terhadap Prestasi Belajar ata Pelajaran Ekonomi Pada Siswa Kelas XI IPS SMA Negeri 1. Jurnal Pendidikan Insan Mandiri. 1-13

Insar,D., Paskalina Th, Lefan \& Melda M (2017). Hubungan Mmotivasi Belajar Dengan Hasil Belajar Biologi Siswa Di SMP 21 Rendani Manokwari. FKIP Mataram

Lee, I-C.(2010). The Effect of Motivation, TotalQuality Theaching and Peer-Assisted Learning on Study Achievement : Empirical Analysis from Vocational Universities of Colleges student in Taiwan. The Journal Of Human Resourse and Adult Learning, 6(Desember), 56-73

Sugiyono. (2012). Statistika untuk Penelitian. Alfabeta. Bandung . (2010). Metode Penelitian Pendidikan Pendekatan Kuantitatif, Kualitatif, dan $R \& D$. Alfabeta. Bandung

Sukardi. (2011). Metodologi Penelitian Pendidikan Kompetensi dan Praktiknya. PT. Bumi Aksara. Jakarta

Slameto. (2015). Belajar dan faktor-faktor Yang Mempengaruhi. Rineka Cipta. Jakarta 